\title{
Carbon and carbon dioxide accumulation by marandu grass under nitrogen fertilization and irrigation ${ }^{1}$
}

\author{
Elisângela Dupas ${ }^{2 *}$, Salatiér Buzetti ${ }^{2}$, Flávio Henrique Silveira Rabêlo ${ }^{3}$, André Luís Sarto ${ }^{4}$ \\ $10.1590 / 0034-737 X 201663030016$
}

\begin{abstract}
Nitrogen $(\mathrm{N})$ is the most limiting nutrient for growth of forage grasses, especially in conditions of low water availability. Therefore, it is important to evaluate the effect of $\mathrm{N}$ fertilization and irrigation on the accumulation of carbon (C) and carbon dioxide $\left(\mathrm{CO}_{2}\right)$ by marandu grass in the Cerrado Paulista, in the rainy and dry seasons. Experiments were conducted to evaluate $\mathrm{N}$ fertilization in each season, with and without irrigation. Five $\mathrm{N}$ rates were used $(0,50,100,150$ and $200 \mathrm{~kg}$ $\mathrm{ha}^{-1}$ per cutting), using urea as $\mathrm{N}$ source, totaling $0,300,600,900$ and $1200 \mathrm{~kg} \mathrm{ha}^{-1}$ in the rainy season and $0,100,200,300$ and $400 \mathrm{~kg} \mathrm{ha}^{-1}$ in the dry season. The experiments were arranged in a split-plot randomized block design. There was no significant interaction $(\mathrm{p}>0.05)$ between $\mathrm{N}$ and time of fertilization in the irrigated experiment. However, $\mathrm{N}$ promoted a quadratic effect in organic matter production (OMP), accumulation of $\mathrm{C}$ and $\mathrm{CO}_{2}$ by marandu grass, while there was no influence of the seasons. In the non-irrigated experiment, the interaction between $\mathrm{N}$ rates and seasons was significant $(\mathrm{p}<0.05)$ only for the rainy season. Organic matter production and $\mathrm{C}$ and $\mathrm{CO}_{2}$ accumulation was greater in the rainy season than in the dry season. Irrigation provided increases of approximately $20 \%$ in $\mathrm{C}$ and $\mathrm{CO}_{2}$ accumulation. The use of $\mathrm{N}$ and irrigation increases the accumulation of $\mathrm{C}$ and $\mathrm{CO}_{2}$ by marandu grass, and this increase is higher during the rainy season.
\end{abstract}

Keywords: global warming, greenhouse effect, forage, Brachiaria brizantha cv. Marandu.

\section{RESUMO}

\section{Acúmulo de carbono e dióxido de carbono pelo capim-marandu sob adubação nitrogenada e irrigação}

O nitrogênio $(\mathrm{N})$ é o nutriente mais limitante ao crescimento de gramíneas forrageiras, principalmente em condições de baixa disponibilidade hídrica, o que justifica avaliar o efeito da adubação nitrogenada e da irrigação no acúmulo de carbono $(\mathrm{C})$ e dióxido de carbono $\left(\mathrm{CO}_{2}\right)$ pelo capim-marandu no Cerrado Paulista, na época das águas e da seca. Para avaliar a fertilização nitrogenada em cada época foram conduzidos experimentos com e sem irrigação. Foram utilizadas cinco doses de $\mathrm{N}\left(0,50,100,150\right.$ e $200 \mathrm{~kg}^{-1} \mathrm{ha}^{-1}$ por corte), aplicadas na forma de ureia, totalizando $0,300,600,900 \mathrm{e} 1200$ $\mathrm{kg} \mathrm{ha}^{-1}$ na época das águas e $0,100,200,300$ e $400 \mathrm{~kg} \mathrm{ha}^{-1}$ na época da seca. O delineamento experimental adotado foi de blocos ao acaso em esquema de parcelas subdivididas. Não houve interação significativa ( $p>0,05)$ entre doses de $\mathrm{N}$ e época de fertilização no experimento irrigado. Entretanto, o fornecimento de $\mathrm{N}$ promoveu efeito quadrático na produção de matéria orgânica (PMO), acúmulo de $\mathrm{C}$ e $\mathrm{CO}_{2}$ pelo capim-marandu, enquanto não houve influência das épocas. No experimento não irrigado a interação entre doses de $\mathrm{N}$ e épocas do ano foi significativa $(\mathrm{p}<0,05)$ somente para a época

\footnotetext{
Submitted on July $2^{\text {nd }}, 2014$ and accepted on November $20^{\text {th }}, 2015$.

${ }^{2}$ Universidade Estadual Paulista, Departamento de Fitossanidade, Engenharia Rural e Solos, Ilha Solteira, São Paulo, Brasil. elidupas@gmail.com; sbuzetti@agr.feis.unesp.br

${ }^{3}$ Universidade de São Paulo, Centro de Energia Nuclear na Agricultura, Departamento de Ciência do Solo, Piracicaba, São Paulo, Brasil. flaviohsr.agro@yahoo.com.br

${ }^{4}$ Empresa André Luís Sarto ME, Ivinhema, Mato Grosso do Sul, Brasil. agrosarto@ hotmail.com

*Corresponding author: elidupas@gmail.com
} 
das águas. Houve maiores $\mathrm{PMO}$ e acúmulos de $\mathrm{C}$ e $\mathrm{CO}_{2}$ no período das águas em relação ao período seco. A irrigação proporcionou incrementos de aproximadamente $20 \%$ no acúmulo de $\mathrm{Ce} \mathrm{CO}_{2}$. O uso de $\mathrm{N}$ e irrigação aumentam o acúmulo de $\mathrm{Ce} \mathrm{CO}_{2}$ pelo capim-marandu, e esse aumento é maior na estação chuvosa.

Palavras-chave: aquecimento global, efeito estufa, forragem, Brachiaria brizantha cv. Marandu.

\section{INTRODUCTION}

Concern over global climate change has been growing worldwide. Global warming results mainly from the emission of $\mathrm{CO}_{2}$ and other greenhouse gases (GHGs) such as methane $\left(\mathrm{CH}_{4}\right)$ and nitrous oxide $\left(\mathrm{N}_{2} \mathrm{O}\right)$, leading to the search of strategies to reduce the sources of greenhouse gas emissions, e.g. C sequestration by vegetation (Carvalho et al., 2010; Cerri et al., 2007a; Cerri et al., 2009).

In pastures, $\mathrm{C}$ assimilation is directed towards the production of fiber and forage (Luyssaert et al., 2008). Thus, the intensification of the production system, through fertilization and irrigation, can be an important tool to mitigate GHGs in this ecosystem (Conant et al., 2001). According to FAO (Food and Agriculture Organization, 2011), Brazil has 196 million hectares of grasslands, and approximately $80 \%$ of this area is in some stage of degradation (Marchão et al., 2007), due to, among other reasons, low soil fertility and lack of nutrient replacement through fertilizer application. For comparison, the annual $\mathrm{CO}_{2}$ sequestration in pasture conducted extensively vary from 4 to $10 \mathrm{t} \mathrm{ha}^{-1}$ in the shoot, while in tropical forage, well-nourished pastures, these values range from 30 to 50 tha $^{-1}$ (Primavesi et al., 2007).

Forage grasses adapted to soil and climatic conditions and of high dry matter productivity (DMP) should be used, as they contribute positively in $\mathrm{CO}_{2}$ sequestration (Conant et al., 2001). In this sense, Brachiaria grasses stand out for being highly productive (Bauer et al, 2011) and highly responsive to fertilization (Rezende et al., 2011; Cabral et al., 2012; Cunha et al., 2012), which is extremely desirable to maximize $\mathrm{C}$ sequestration and consequently to mitigate GHGs (Conant et al., 2001).

According to Primavesi et al. (2007), 60\% of tropical soils undergo water stress, which can cause severe photosynthesis inhibition (Pinheiro \& Chaves, 2011), and $36 \%$ of tropical soils have low nutrient reserves, making irrigation and fertilization of pastures in these areas essential. Nitrogen fertilization stands out in this context for being the most limiting nutrient to plant growth (Rezende et al., 2015). Lack of $\mathrm{N}$ can directly affect photosynthesis, by affecting the synthesis and activity of the enzyme ribulose 1,5-bisphosphate carboxylase (RUBISCO), responsible for $\mathrm{CO}_{2}$ assimilation (Pinheiro \& Chaves, 2011), and indirectly the GHGs mitigation, as the
C sequestration by shoots is compromised by the reduction of photosynthesis (Primavesi et al., 2007).

Therefore, this study aimed to evaluate the accumulation of carbon $(\mathrm{C})$ and carbon dioxide $\left(\mathrm{CO}_{2}\right)$, based on dry matter productivity (DMP) and organic matter content $(\mathrm{OM})$ of marandu grass (Brachiaria brizantha Stapf. cv. Marandu) under $\mathrm{N}$ rates and irrigation in the Cerrado Paulista during the rainy and dry seasons.

\section{MATERIAL AND METHODS}

The experiments were conducted in a Typic Dark soil, eutrophic, sandy texture (Empresa Brasileira de Pesquisa Agropecuária - EMBRAPA, 2013), at the UNESP - Universidade Estadual Paulista "Júlio de Mesquita Filho" in Teaching and Research Farm, Ilha Solteira - SP, located on the left bank of the Parana River ( $20^{\circ} 21^{\prime} \mathrm{S}$ and $51^{\circ} 22^{\prime} \mathrm{W}$ ), $326 \mathrm{~m}$ altitude, in an area previously occupied by Panicum maximum Jacq. cv. Colonião undergrazed. Table 1 shows the soil chemical analyzes carried out during the experiment.

The experimental areas were prepared by conventional system with one plowing and two disking, then sowing of marandu grass. At sowing, $20 \mathrm{~kg} \mathrm{ha}^{-1} \mathrm{~N}$ were applied as urea $(45 \% \mathrm{~N})$; phosphorus (superphosphate - $18 \% \mathrm{P}_{2} \mathrm{O}_{5}$ ) and potassium (potassium chloride $-60 \% \mathrm{~K}_{2} \mathrm{O}$ ) were provided to adjust the phosphorus levels at $30 \mathrm{mg} \mathrm{dm}^{-3}$; and potassium occupying $5 \%$ of the cation exchange capacity (CEC).

Experiments were conducted with and without irrigation (Figure 1), and the $\mathrm{N}$ fertilization was evaluated during the rainy and dry seasons. The irrigated experiment used a fixed sprinkler irrigation system with nozzles spaced $12 \times 12 \mathrm{~m}$, with an average rainfall of $7.0 \mathrm{~mm} \mathrm{~h}^{-1}$ and mean Christiansen's uniformity coefficient of $84.5 \%$. The irrigation had a 3-day schedule with replacement of the reference evapotranspiration estimated by Penman Monteith (Allen et al., 1998) and crop coefficient of 1.0.

Five $\mathrm{N}$ rates $\left(0,50,100,150\right.$ and $200 \mathrm{~kg}^{-1} \mathrm{ha}^{-1}$ after each cutting) were applied as urea, resulting in the application of $0,300,600,900$ and $1200 \mathrm{~kg} \mathrm{ha}^{-1}$ in the rainy season and $0,100,200,300$ and $400 \mathrm{~kg} \mathrm{ha}^{-1}$ in the dry season. The experiments were arranged in a split plot randomized block design, with plots represented by $\mathrm{N}$ rates and the subplots by seasons (rainy and dry seasons). The plot areas were $9.0 \mathrm{~m}^{2}(3 \times 3 \mathrm{~m})$ spaced $2 \mathrm{~m}$ apart. 
After the initial growth, the first cutting of marandu grass was performed and $\mathrm{N}$ fertilization was applied to the subplots. Every after three cuttings $18 \mathrm{~kg} \mathrm{ha}^{-1} \mathrm{~K}_{2} \mathrm{O}$ (potassium chloride) were applied, and a new soil chemical analysis was performed to adjust the phosphorus again to $30 \mathrm{mg} \mathrm{dm}^{-3}$, with potassium occupying $5 \%$ of CEC, in order to meet phosphorus and potassium plant requirements and optimize the $\mathrm{N}$ response. Five months after the start of $\mathrm{N}$ fertilization, $81 \mathrm{~kg} \mathrm{ha}^{-1} \mathrm{P}_{2} \mathrm{O}_{5}$ (superphosphate) and $96 \mathrm{~kg} \mathrm{ha}^{-1} \mathrm{~K}_{2} \mathrm{O}$ (chloride potassium) were applied to the plots, and seven months later, $71 \mathrm{~kg} \mathrm{ha}^{-1} \mathrm{P}_{2} \mathrm{O}_{5}$ (superphosphate) and $130 \mathrm{~kg} \mathrm{ha}^{-1}$ of $\mathrm{K}_{2} \mathrm{O}$ (potassium chloride) were also applied.
Cuttings were performed manually, $15 \mathrm{~cm}$ above the ground in the center of the subplots, in an area of $1.0 \mathrm{~m}^{2}$. The intervals between cuttings ranged from 28 to 32 days in the rainy season, and 40-45 days in the dry season. The remaining biomass in the area was mechanically mowed, removed from the plot, and then $\mathrm{N}$ was applied to the subplots.

The clipped forage was packed in paper bags and then incubated in a forced circulation oven at $60^{\circ} \mathrm{C}$, for 72 hours, to determine dry matter content. Then, the samples were ground in a Wiley mill, with a $1 \mathrm{~mm}$ mesh screen, and analyzed for the content of organic matter (total carbon) following the method described by Silva (2002).

Table 1: Soil chemical analysis of the experimental areas in the layer $0-20 \mathrm{~cm}$

\begin{tabular}{|c|c|c|c|c|c|c|c|c|c|c|c|}
\hline \multirow{5}{*}{ Experiments } & P-resin & O.M. & pH & $\mathbf{K}$ & $\mathbf{C a}$ & Mg & $\mathrm{H}+\mathrm{Al}$ & Al & SB & CEC & $\mathbf{V}$ \\
\hline & $\mathbf{m g ~ d m}{ }^{-3}$ & $g_{d m} \mathbf{d m}^{-3}$ & $\left(\mathrm{CaCl}_{2}\right)$ & \multicolumn{7}{|c|}{$\mathrm{mmol}_{\mathrm{c}} \mathrm{dm}^{-3}$} & $\%$ \\
\hline & \multicolumn{11}{|c|}{ Initial analysis - Before Seeding } \\
\hline & 13 & 17 & 5.2 & 2.2 & 35 & 7 & 16 & 0 & 44.2 & 60.2 & 73 \\
\hline & \multicolumn{11}{|c|}{3 months after start of nitrogen fertilization } \\
\hline Irrigated & 19 & 23 & 4.9 & 1.4 & 16 & 6 & 25 & 0 & 23.4 & 48.6 & 49 \\
\hline \multirow[t]{2}{*}{ Non-irrigated } & 19 & 24 & 5.0 & 1.2 & 20 & 4 & 25 & 0 & 25.2 & 49.6 & 50 \\
\hline & \multicolumn{11}{|c|}{7 months after start of nitrogen fertilization } \\
\hline Irrigated & 20 & 21 & 4.9 & 1.3 & 16 & 4 & 26 & 0 & 21.3 & 47.3 & 45 \\
\hline Non-irrigated & 21 & 21 & 4.9 & 1.3 & 16 & 3 & 28 & 0 & 20.3 & 48.3 & 42 \\
\hline \multicolumn{12}{|c|}{11 months after start of nitrogen fertilization } \\
\hline Irrigated & 20 & 20 & 4.7 & 1.5 & 15 & 4 & 26 & 1 & 20.5 & 46.5 & 44 \\
\hline Non-irrigated & 27 & 21 & 4.6 & 1.7 & 16 & 4 & 26 & 1 & 21.7 & 47.7 & 45 \\
\hline
\end{tabular}

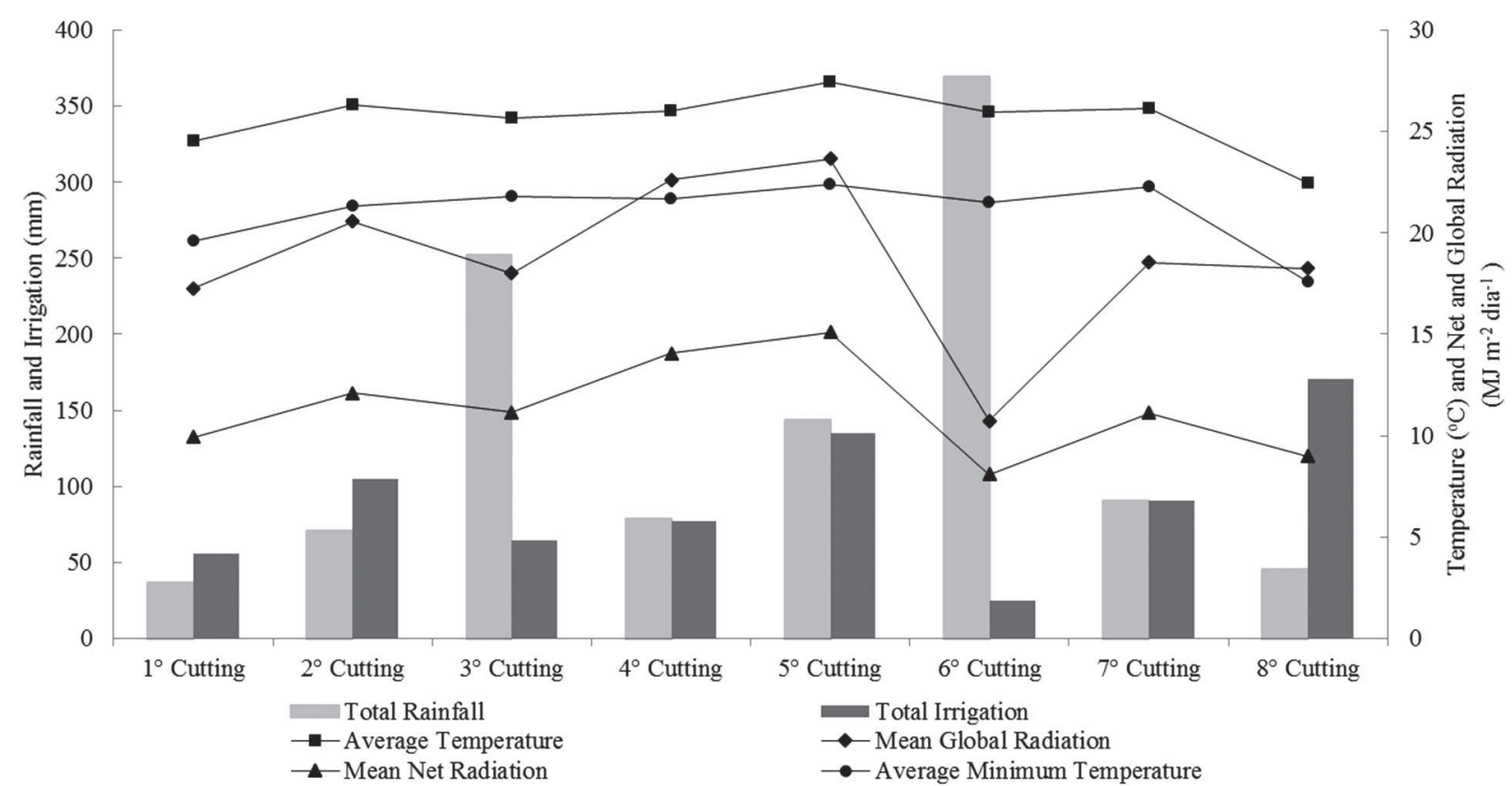

Figure 1. Total rainfall, total irrigation, average and minimum temperature, average global radiation and average net radiation, referring to the eight marandu grass cuttings. 
Dry matter productivity (DMP) was calculated by multiplying the amount of green mass $\left(\mathrm{kg} \mathrm{m}^{-2}\right)$ by the content of the initial dry matter, and then extrapolating to one hectare. The estimates of OMP, $\mathrm{C}$ and $\mathrm{CO}_{2}$ sequestration were based on the DMP and OM content (\%) (Table 2), using the respective equations described by Primavesi et al. (2007): OMP $\left(\mathrm{t} \mathrm{ha}^{-1}\right)=\mathrm{DMP} \times \mathrm{OM} \% ; \mathrm{C}(\mathrm{t}$ $\left.\mathrm{ha}^{-1}\right)=\mathrm{OMP} / 1.724$ and $\mathrm{CO}_{2}\left(\mathrm{t} \mathrm{ha}^{-1}\right)=\mathrm{C}\left(\mathrm{t} \mathrm{ha}^{-1}\right) \times 3.67$.

Analyses of data separated and joined were carried out after verification of normality and homogeneity of variances, and by applying the analysis of variance ( $F$ test). When significance was found, regression analysis was performed for $\mathrm{N}$ rates and mean comparison for the seasons (Tukey test at 5\% probability). Next, a combined analysis of the irrigated with the non-irrigated experiments was performed through the comparison of means (Tukey test at 5\% probability) of the factor irrigation using the Statistical Analysis System (SAS, 2004).

\section{RESULTS AND DISCUSSION}

There was no significant interaction $(p>0.05)$ between $\mathrm{N}$ and seasons in the irrigated experiment due to the inexistent water restriction, which is the main limiting factor for DMP in the dry season. However, $\mathrm{N}$ supply provided a quadratic increase in $\mathrm{OMP}$ and $\mathrm{C}$ and $\mathrm{CO}_{2}$ sequestration by marandu grass (Figure 2). It is known that $\mathrm{N}$ is the nutrient that most influence plant growth (Rezende et al., 2015), increasing plant DMP linearly up the point where other growth factors become limiting. Thus, OMP and sequestration of $\mathrm{C}$ and $\mathrm{CO}_{2}$ reflected the effect of $\mathrm{N}$ on DMP when there was adequate water availability.

Sequestration of $\mathrm{C}$ above $1 \mathrm{tha}^{-1}$ and $\mathrm{CO}_{2}$ above $5 \mathrm{tha}^{-1}$, per cutting, by marandu grass with $\mathrm{N}$ supply was verified, demonstrating that $\mathrm{N}$ fertilization associated with irrigation is essential to increase GHGs sequestration by pastures in a first moment. Pinheiro \& Chaves (2011) pointed out that the lack of $\mathrm{N}$ can directly affect photosynthesis, by affecting the synthesis and activity of the enzyme

Table 2: Dry matter productivity (DMP) and organic matter content of marandu grass with or without irrigation and nitrogen rates for the eight cutings

\begin{tabular}{|c|c|c|c|c|c|c|c|c|c|c|}
\hline & \multicolumn{5}{|c|}{$\operatorname{DMP}\left(\mathrm{tha}^{-1}\right)$} & \multicolumn{5}{|c|}{ Organic matter $(\%)$} \\
\hline & \multicolumn{10}{|c|}{ Nitrogen rates $\left(\mathrm{kg} \mathrm{ha}^{-1}\right)$} \\
\hline & $\mathbf{0}$ & 50 & 100 & 150 & 200 & $\mathbf{0}$ & 50 & 100 & 150 & 200 \\
\hline & \multicolumn{10}{|c|}{ Cutting 1} \\
\hline Irrigated & 1.96 & 4.34 & 5.84 & 6.46 & 6.29 & 89.31 & 90.52 & 89.57 & 89.80 & 89.45 \\
\hline \multirow[t]{2}{*}{ Non-irrigated } & 1.62 & 2.63 & 4.54 & 5.02 & 4.89 & 90.33 & 90.70 & 90.54 & 90.05 & 90.33 \\
\hline & \multicolumn{10}{|c|}{ Cutting 2} \\
\hline Irrigated & 0.80 & 2.82 & 3.42 & 3.37 & 3.79 & 88.86 & 90.37 & 88.68 & 89.60 & 89.61 \\
\hline \multirow[t]{2}{*}{ Non-irrigated } & 0.61 & 1.64 & 2.21 & 1.91 & 2.31 & 88.94 & 89.47 & 89.21 & 88.38 & 88.56 \\
\hline & \multicolumn{10}{|c|}{ Cutting 3} \\
\hline Irrigated & 0.71 & 1.45 & 1.80 & 1.63 & 1.86 & 89.13 & 89.16 & 88.77 & 89.06 & 89.19 \\
\hline \multirow[t]{2}{*}{ Non-irrigated } & 0.92 & 3.82 & 4.80 & 6.03 & 6.46 & 90.43 & 89.42 & 89.71 & 89.75 & 90.02 \\
\hline & \multicolumn{10}{|c|}{ Cutting 4} \\
\hline Irrigated & 2.59 & 3.56 & 4.27 & 4.65 & 5.62 & 89.12 & 89.48 & 89.35 & 89.28 & 89.33 \\
\hline \multirow[t]{2}{*}{ Non-irrigated } & 20.60 & 2.62 & 2.50 & 2.46 & 2.25 & 90.20 & 90.33 & 90.09 & 89.69 & 90.44 \\
\hline & \multicolumn{10}{|c|}{ Cutting 5} \\
\hline Irrigated & 0.91 & 2.51 & 3.26 & 2.45 & 3.34 & 89.11 & 89.66 & 89.49 & 89.68 & 89.69 \\
\hline \multirow[t]{2}{*}{ Non-irrigated } & 0.53 & 2.41 & 3.20 & 4.17 & 4.65 & 88.82 & 90.06 & 90.12 & 90.34 & 91.97 \\
\hline & \multicolumn{10}{|c|}{ Cutting 6} \\
\hline Irrigated & 1.51 & 3.60 & 3.45 & 4.69 & 4.04 & 90.50 & 90.27 & 90.59 & 90.64 & 90.64 \\
\hline \multirow[t]{2}{*}{ Non-irrigated } & 1.65 & 4.74 & 4.94 & 3.61 & 3.64 & 91.64 & 90.49 & 90.21 & 90.06 & 90.76 \\
\hline & \multicolumn{10}{|c|}{ Cutting 7} \\
\hline Irrigated & 1.29 & 1.55 & 1.96 & 2.08 & 1.64 & 89.40 & 88.81 & 89.47 & 90.18 & 89.73 \\
\hline \multirow[t]{2}{*}{ Non-irrigated } & 1.61 & 1.18 & 1.71 & 1.65 & 1.98 & 89.21 & 89.08 & 89.63 & 90.51 & 90.03 \\
\hline & \multicolumn{10}{|c|}{ Cutting 8} \\
\hline Irrigated & 1.08 & 3.18 & 3.20 & 3.76 & 4.28 & 87.03 & 88.77 & 88.85 & 89.60 & 89.68 \\
\hline Non-irrigated & 0.88 & 1.57 & 0.76 & 1.13 & 0.60 & 87.61 & 89.10 & 89.17 & 90.43 & 90.91 \\
\hline
\end{tabular}

Rev. Ceres, Viçosa, v. 63, n.3, p. 387-393, mai/jun, 2016 
responsible for the assimilation of $\mathrm{CO}_{2}$ (RUBISCO), limiting the accumulation of $\mathrm{C}$ and $\mathrm{CO}_{2}$ by the vegetation. However, it is essential to adopt the correct management of $\mathrm{N}$ fertilization because of the emissions of $\mathrm{N}_{2} \mathrm{O}$ (and other GHGs) arising from the use of $\mathrm{N}$ fertilizers (Barcellos et al., 2008; Virkajarvi et al., 2010) when the source and the form of application recommended for each situation are disregarded.

In the non-irrigated experiment, the interaction between $\mathrm{N}$ rates and seasons was significant $(\mathrm{p}<0.05)$ only for the rainy season. This result can be attributed to a higher rainfall recorded in the rainy season (>900 mm) compared with the rainfall recorded in the dry season $(<200 \mathrm{~mm})$ (Figure 1). The primary ion-root contact mechanism in the absorption of $\mathrm{N}$ is the mass flow, which is dependent on water (Malavolta et al., 1989). Therefore, low water availability may limit the plant metabolism, uptake of $\mathrm{N}$ and, consequently, the plant productive response in terms of production (Primavesi et al., 2007, Pinheiro \& Chaves, 2011). According to Lopes et al. (2005), the DMP and, consequently, the OMP, the sequestration of $\mathrm{C}$ and $\mathrm{CO}_{2}$ by grasses during the dry season can be $70 \%$ lower than in the rainy season. The highest OMP $\left(3686 \mathrm{~kg} \mathrm{ha}^{-1}\right)$ and sequestration of $\mathrm{C}\left(2136 \mathrm{~kg} \mathrm{ha}^{-1}\right)$ and $\mathrm{CO}_{2}\left(7846 \mathrm{~kg} \mathrm{ha}^{-1}\right)$ were recorded with application of $162 \mathrm{~kg} \mathrm{ha}^{-1} \mathrm{~N}$ in the rainy season (Figure 3).

Carbon dioxide sequestration per cutting $\left(7846 \mathrm{~kg} \mathrm{ha}^{-1}\right)$ was extremely high and confirms the beneficial effects caused by $\mathrm{N}$ fertilization and irrigation compared with the range between 30 and $50 \mathrm{tha}^{-1}$ annual cited as indicative of well-managed pastures by Primavesi et al. (2007). Assuming that the climatic conditions remained constant, the final $\mathrm{CO}_{2}$ accumulation in the rainy season would be approximately $47 \mathrm{tha}^{-1}$. Paulino \& Teixeira (2009) reported that the lack of $\mathrm{N}$ fertilization and less frequent grazing resulted in loss of $57 \mathrm{~g}$ of $\mathrm{C}$ per square meter per year to the atmosphere. This report confirms the importance of $\mathrm{N}$ fertilization on GHGs mitigation.

Table 3 shows the effect of season in OMP, accumulation of $\mathrm{C}$ and accumulation of $\mathrm{CO}_{2}$ by marandu grass in the non-irrigated experiment. There was higher ( $\mathrm{p}$ $<0.05) \mathrm{OMP}$ and sequestration of $\mathrm{C}$ and $\mathrm{CO}_{2}$ in the rainy season due to increased water availability (>900 mm) compared with the dry season $(<200 \mathrm{~mm}$ ) (Figure 1$)$. The water stress affects various physiological processes of plants, generally increasing the stomatal conductance, reducing perspiration and hence the $\mathrm{CO}_{2}$ supply to perform photosynthesis (Taiz \& Zeiger, 2009). Therefore, biomass production and $\mathrm{C}$ sequestration by plants are compromised in environments with low water availability, even when there is adequate nutrient supply.

Loss et al. (2013) evaluated the effect of irrigation in the stock of total organic carbon (TOC) of an Oxisol with Cynodon grass and found that the irrigated area had the highest TOC values, regardless of the depth of evaluation. The authors attributed the result to higher production of green mass, under irrigation. It is noteworthy that the stock of $\mathrm{C}$ in the soil is derived in part from the decomposition of

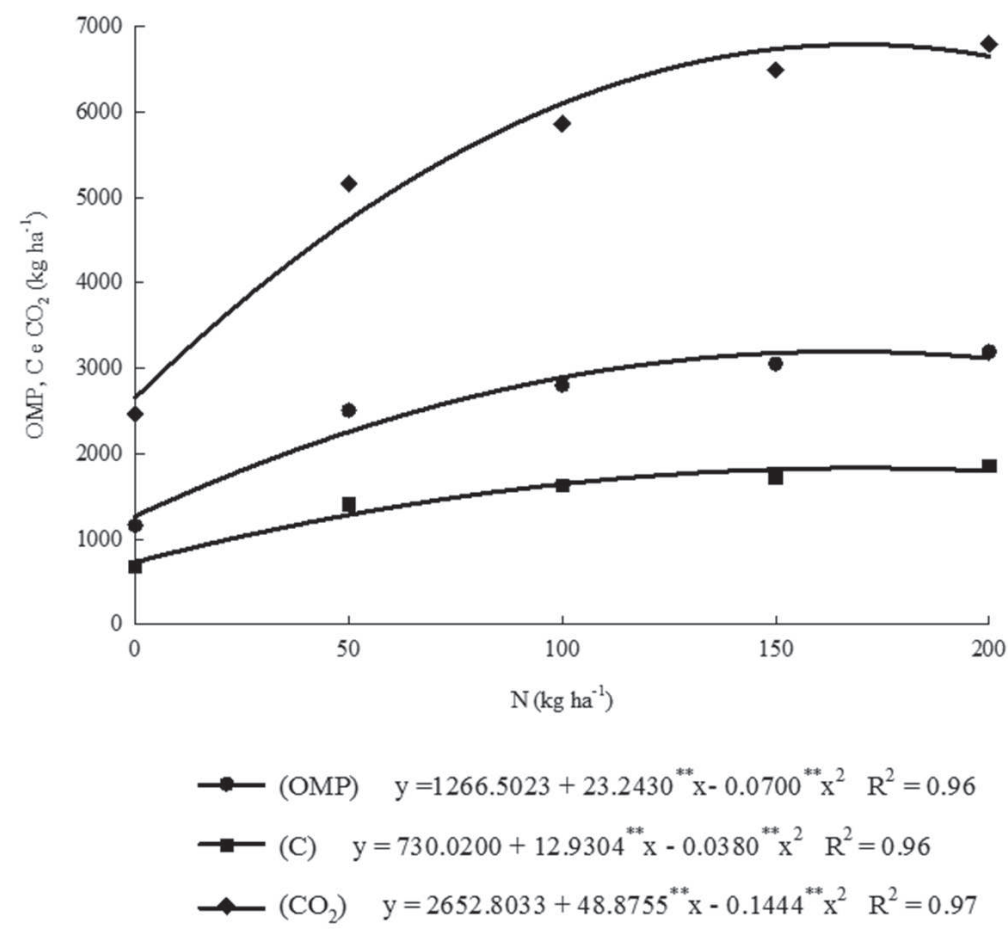

Figure 2: Means per cutting of the estimates for organic matter productivity (OMP), sequestration of carbon (C) and carbon dioxide $\left(\mathrm{CO}_{2}\right)$ by marandu grass as a function of nitrogen rates $(\mathrm{N})$ in the irrigated experiment. 
Table 3: Mean per cutting of organic matter productivity estimates (OMP), accumulation of carbon (C) and carbon dioxide $\left(\mathrm{CO}_{2}\right)$ by marandu grass as a function of the seasons for the non-irrigated experiment

\begin{tabular}{lccc}
\hline \multirow{2}{*}{ Seasons $^{1}$} & OMP & $\mathbf{C}$ & CO $_{2}$ \\
\cline { 2 - 4 } & & $\mathbf{k g ~ h a}^{\mathbf{1}}$ & \\
\hline Rainy & $2850.02 \mathrm{a}$ & $1653.15 \mathrm{a}$ & $6067.05 \mathrm{a}$ \\
Dry & $1229.51 \mathrm{~b}$ & $678.33 \mathrm{~b}$ & $2489.47 \mathrm{~b}$ \\
\hline
\end{tabular}

\begin{tabular}{llcc}
\hline C.V. $(\%)$ & 13 & 15 & 15 \\
\hline
\end{tabular}

${ }^{1}$ Means followed by different letters in the columns are significantly different by the Tukey test at $5 \%$ significance.

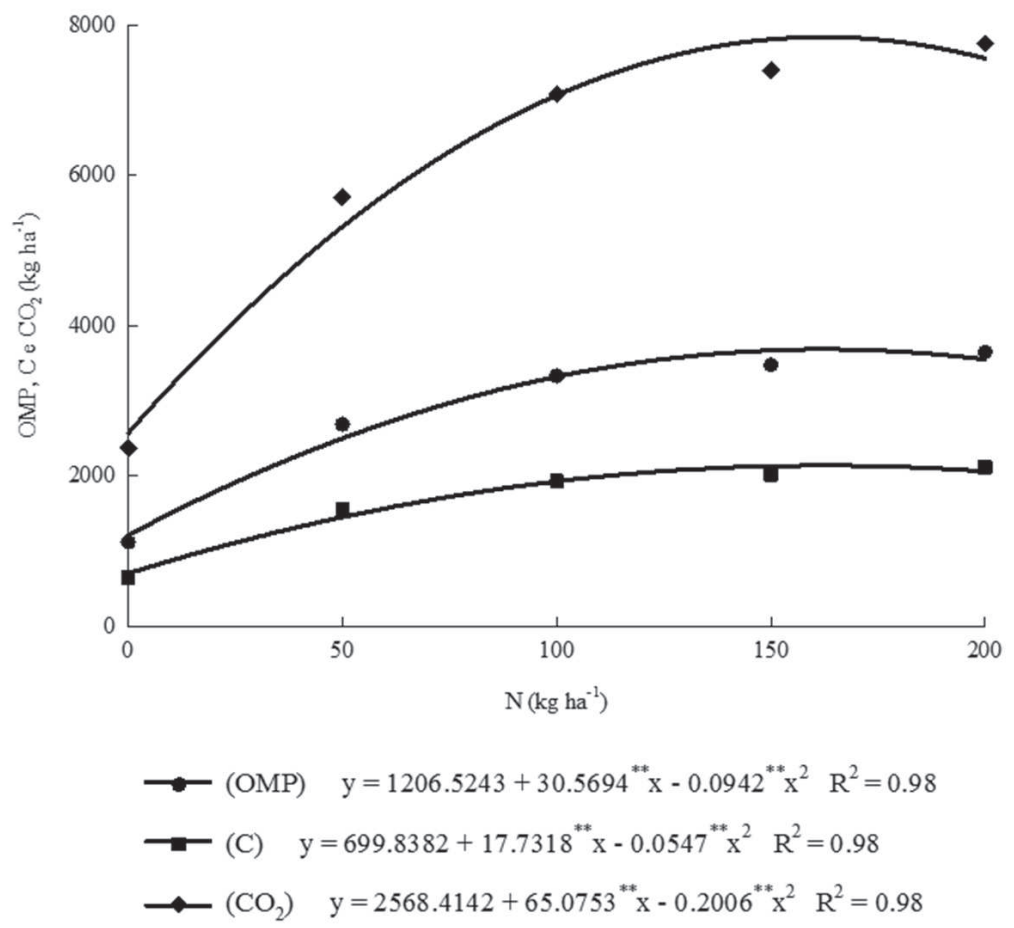

Figure 3: Means per cutting of the estimates for organic matter productivity (OMP), sequestration of carbon (C) and carbon dioxide $\left(\mathrm{CO}_{2}\right)$ by marandu grass as a function of nitrogen rates $(\mathrm{N})$ in the non-irrigated experiment.

Table 4: Mean per cutting of organic matter productivity estimates (OMP), sequestration of carbon (C) and carbon dioxide $\left(\mathrm{CO}_{2}\right)$ by marandu grass as a function of the factor irrigation

\begin{tabular}{|c|c|c|c|}
\hline \multirow{2}{*}{ Experiments $^{1}$} & OMP & $\mathrm{C}$ & $\mathrm{CO}_{2}$ \\
\hline & \multicolumn{3}{|c|}{ kg ha-1 } \\
\hline Irrigated & $2540.24 a$ & $1454.44 \mathrm{a}$ & $5374.70 \mathrm{a}$ \\
\hline Non-Irrigated & $2039.24 b$ & $1165.74 b$ & $4278.26 \mathrm{~b}$ \\
\hline C.V. $(\%)$ & 17 & 15 & 15 \\
\hline
\end{tabular}

${ }^{1}$ Means followed by different letters in the columns are significantly different by the Tukey test at $5 \%$ significance.

plant residues, which at some point captured $\mathrm{CO}_{2}$ from the atmosphere to produce biomass (Ministry of Agriculture, Livestock and Supply - MAPA, 2011; Matheus, 2012). Thus, the results obtained by Loss et al. (2013) confirm the benefit provided by irrigation in the mitigation of greenhouse gases.

At the end of the trial period, not considering the effect of season and $\mathrm{N}$ rates, the factor irrigation was predominant to maximize the OMP and sequestration of $\mathrm{C}$ and $\mathrm{CO}_{2}$ by marandu grass (Table 4). Irrigation provided increments of approximately $20 \%$ in sequestration of $\mathrm{C}$ and $\mathrm{CO}_{2}$ compared with the non-irrigated experiment, contributing considerably to the mitigation of GHGs.

The Brazilian herd contingent associated with the large area occupied by pastures point out the importance and impacts of livestock activity such as GHGs emitting source or as a drain, depending on the management used (Saussana et al., 2007). It is therefore essential to optimize 
the conditions for the cultivation of grasses, since under suitable vegetable mass production, grasses are able to sequester substantial amounts of $\mathrm{C}$ fixing it to the soil in the organic form (Cerri et al., 2007b).

\section{CONCLUSIONS}

Nitrogen supply and irrigation increases the potential sequestration of $\mathrm{C}$ and $\mathrm{CO}_{2}$ by marandu grass, and this increase is higher during the rainy season.

\section{REFERENCES}

Allen RG, Pereira LS, Raes D \& Smith M (1998) Crop evapotranspiration-guidelines for computing crop water requirements. Rome, FAO Irrigation and Drainage. 56p.

Barcellos AO, Ramos AKB, Vilela L \& Martha Junior GB (2008) Sustentabilidade da produção animal baseada em pastagens consorciadas e no emprego de leguminosas exclusivas, na forma de banco de proteína, nos trópicos brasileiros. Revista Brasileira de Zootecnia, 37:51-67.

Bauer MO, Pacheco LPA, Chichorro JF, Vasconcelos LV \& Pereira DFC (2011) Produção e características estruturais de cinco forrageiras do gênero Brachiaria sob intensidades de cortes intermitentes. Ciência Animal Brasileira, 12:17-25.

Cabral WB, Souza AL, Alexandrino E, Toral FLB, Santos JN \& Carvalho MVP (2012) Características estruturais e agronômicas da Brachiaria brizantha cv. Xaraés submetida a doses de nitrogênio. Revista Brasileira de Zootecnia, 41:846-855.

Carvalho JLN, Avanzi JC, Silva MLN, Mello CR \& Cerri CEP (2010) Potencial de sequestro de carbono em diferentes biomas do Brasil. Revista Brasileira de Ciência do Solo, 34:277-289.

Cerri CC, Maia SMF, Galdos MV, Cerri CEP, Feigl BJ \& Bernoux M (2009) Brazilian greenhouse gas emissions: the importance of agriculture and livestock. Scientia Agricola, 66:831-843.

Cerri CEP, Easter M, Paustian K, Killian K, Coleman K, Bernoux M, Falloon P, Powlson DS, Batjes N, Milne E \& Cerri CC (2007b) Simulating SOC changes in 11 land use change from Brazilian Amazon whith RothC and Century models. Agriculture, Ecosystems and Environment, 122:46-57.

Cerri CEP, Sparovek G, Bernoux M, Easterling WE, Melillo JM \& Cerri CC (2007a) Tropical agriculture and global warming: impacts and mitigation options. Scientia Agricola, 64:83-89.

Conant RT, Paustian K \& Elliott ET (2001) Grassland management and conversion into grassland: effects on soil carbon. Ecological Applications, 11:343-355.

Cunha FF, Ramos MM, Alencar CAB, Oliveira RA, Cóser AC, Martins CE, Cecon PR \& Araújo RAS (2012) Produtividade da Brachiaria brizantha cv. Xaraés em diferentes manejos e doses de adubação, períodos de descanso e épocas do ano. Idesia, 30:75-82.

Embrapa - Empresa Brasileira de Pesquisa Agropecuária (2013) Centro Nacional de Pesquisa de Solos. Sistema Brasileiro de Classificação de Solos. $3^{\mathrm{a}}$ ed. Brasília, Embrapa, 353p.

FAO - Food And Agriculture Organization (2011) FAO statistical database. Disponível em: <http://faostat.fao.org/site/291/ default.aspx>. Acessado em: 12 de fevereiro de 2011.

Lopes RS, Fonseca DM, Oliveira RA, Andrade AC, Nascimento Júnior D \& Mascarenhas AG (2005) Efeito da irrigação e adubação na disponibilidade e composição bromatológica da massa seca de lâminas foliares de capim-elefante. Revista Brasileira de Zootecnia, 34:20-29.
Loss A, Coutinho FS, Pereira MG, Costa e Silva RA, Torres JLR \& Ravelli Neto A (2013) Fertilidade e carbono total e oxidável de Latossolo de Cerrado sob pastagem irrigada e de sequeiro. Ciência Rural, 43:426-432.

Luyssaert S, Schulze ED, Borner A, Knohl A, Hessenmoller D, Law BE, Ciais P \& Grace J (2008) Old-growth forests as global carbon sinks. Nature, 455:213-215.

Malavolta E, Vitti GC \& Oliveira SA (1989) Avaliação do estado nutricional das plantas: princípios e aplicações. Piracicaba, Potafos. 201p.

Marchão RL, Balbino LC, Silva EM, Santos Junior JDG, Sá MAC, Vilela L \& Becquer T (2007) Qualidade física de um Latossolo Vermelho sob sistemas de integração lavoura-pecuária no Cerrado. Pesquisa Agropecuária Brasileira, 42:873-882.

Matheus MT (2012) Sequestro de carbono sob a óptica florestal no Brasil. Revista Trópica - Ciências Agrárias e Biológicas, 6:104-116.

MAPA - Ministério da Agricultura, Pecuária e Abastecimento (2011) O Aquecimento Global e a Agricultura de Baixa Emissão de Carbono. Brasília, MAPA/Embrapa/FEBRAPDP. 75p.

Paulino VT \& Teixeira EML (2009) Sustentabilidade de pastagem: Manejo adequado como medida redutora da emissão de Gases Efeito Estufa. Disponível em: <http:// http:// www.iz.sp.gov.br/pdfs/1261419672.pdf>. Acessado em: 15 de junho 2014.

Pinheiro C \& Chaves M (2011) Photosynthesis and drought: can we make metabolic connections from available data? Journal of Experimental Botany, 62:869-882.

Primavesi O, Arzabe C \& Pedreira MS (2007) Aquecimento global e mudanças climáticas: uma visão integrada tropical. São Carlos, Embrapa Pecuária Sudeste. 213p.

Rezende AV, Lima JF, Rabelo CHS, Rabêlo FHS, Nogueira DA, Carvalho M, Faria Júnior DCNA \& Barbosa LA (2011) Características morfofisiológicas da Brachiaria brizantha cv. Marandu em resposta à adubação fosfatada. Agrarian, 4:335-343.

Rezende AV, Rabêlo FHS, Rabelo CHS, Lima PP, Barbosa LA, Abud MC \& Souza FRC (2015) Características estruturais, produtivas e bromatológicas dos capins Tifton 85 e Jiggs fertilizados com alguns macronutrientes. Semina: Ciências Agrárias, 36:1507-1518.

SAS Institute Inc. (2004) JMP Statistics and Graphics Guide. Versão 9.1.2. Cary, SAS Institute Inc.

Soussana JF, Allard V, Pilegaard K, Ambus P, Amman C, Campbell C, Ceschia E, Clifton-Brown J, Czobel S, Domingues R, Flechard C, Fuhrer J, Hensen A, Horvath L, Jones M, Kasper G, Martin C, Nagy Z, Neftel A, Raschi A, Baronti S, Ress RM, Skiba U, Stefani P, Manca G, Sutton M, Tuba Z \& Valentini R (2007) Full accounting of the greenhouse gas $\left(\mathrm{CO}_{2}, \mathrm{~N}_{2} \mathrm{O}, \mathrm{CH}_{4}\right)$ budget of nine European grassland sites. Agriculture, Ecossistems and Environment, 121:121-134.

Silva DJ \& Queiroz AC (2002) Análise de alimentos: métodos químicos e biológicos. $3^{\mathrm{a}}$ ed. Viçosa, UFV. 235 p.

Taiz L \& Zeiger E (2009) Fisiologia vegetal. 4a ed. Porto Alegre, Artmed. 819p.

Virkajarvi P, Maljanen M, Saarijarvi K, Haapala J \& Martikainen PJ (2010) $\mathrm{N}_{2} \mathrm{O}$ emissions from boreal grass and grass - clover pasture soils. Agriculture, Ecosystems and Environment, 137:5967. 